\title{
A study of lung function in coalworkers' pneumoconiosis
}

\author{
S ZHICHENG \\ From the Department of Occupational Medicine, Third Hospital, Beijing Medical University, Beijing, China
}

Simple lung function and maximal expiratory flow volume curves (MEFV) were measured in 101 patients with simple and complicated coalworkers' pneumoconiosis (CWP) and compared with the data from healthy subjects and from miners exposed to dust. The purpose of the study was to show pulmonary functional deficits in these patients and to help determine their degree of disability.

\section{Subjects and methods}

The study included 65 patients with simple CWP, 36 patients with complicated CWP, and 30 miners exposed to coal dust in coalmines. All were men with 10-20 years underground. Their ages ranged from 32 to 63 , the average ages being $52 \cdot 3,51 \cdot 2$, and 48.4 years, respectively. Thirty healthy male workers with no dust exposure served as controls. Their average age was $44 \cdot 3$ (range $26-55$ ). The mean age was not significantly different in these groups $(p>0.05)$.

A Discom-15 spirometer, produced by Japanese CHEST cooperation, was used to measure vital capacity (VC), forced vital capacity (FVC), forced expiratory volume in one second $\left(\mathrm{FEV}_{1}\right)$, the $\mathrm{FEV}_{1} / \mathrm{FVC}$, and the $\mathrm{FEV}_{1} / \mathrm{VCPR}$. The forced midexpiratory flow $\left(\mathrm{FEF}_{25}-75 \%\right)$ was calculated from the obtained spirogram. In addition, the group mean values of VC and FVC were expressed as the

Accepted 23 September 1985

Table 1 Results of the simple lung function measurements (mean $\pm S D$ )

\begin{tabular}{|c|c|c|c|c|}
\hline Parameter & $\stackrel{(A)}{\text { Controls }(n=30)}$ & $\begin{array}{l}\text { (B) } \\
\text { Miners exposed to } \\
\text { dust }(n=30)\end{array}$ & $\begin{array}{l}\text { (C) } \\
\text { Patients with simple } \\
C W P(C)(n=56)\end{array}$ & $\begin{array}{l}\text { (D) } \\
\text { Patients with } \\
\text { complicated } C W P \\
(n=36)\end{array}$ \\
\hline $\begin{array}{l}\text { VC (1) } \\
\text { VC ( } \% \text { of pred) } \\
\text { FVC (1) } \\
\text { FVC (\% of pred) } \\
\text { FEV } 1 \text { (1) } \\
\text { FEF }(L / S) \text { FEV }_{1} / \text { FVC }(\%) \\
\left.\text { FEV }_{1} / \text { VCPR( } \%\right)\end{array}$ & $\begin{array}{c}4.20 \pm 0.54 \\
106 \cdot 12 \pm 14.82 \\
4 \cdot 12 \pm 0.58 \\
102.32 \pm 18 \cdot 10 \\
3.58 \pm 0.54 \\
3.31 \pm 0.86 \\
86.91 \pm 10 \cdot 10 \\
85.14 \pm 12.64\end{array}$ & $\begin{array}{c}3.94 \pm 0.68 \\
104.16 \pm 14.73 \\
3.87 \pm 0.78 \\
99.10 \pm 16.70 \\
3.27 \pm 0.66 \\
2.89 \pm 0.95 \\
84.47 \pm 6.15 \\
84.13 \pm 14.42\end{array}$ & $\begin{array}{c}3.67 \pm 0.65 \\
96.32 \pm 16.12 \\
3.54 \pm 0.28 \\
98.32 \pm 16.68 \\
2.89 \pm 0.43 \\
2.46 \pm 1.10 \\
81.63 \pm 8.33 \\
82.35 \pm 12.38\end{array}$ & $\begin{array}{c}3.11 \pm 0.46 \\
85.33 \pm 15.79 \\
3.01 \pm 0.52 \\
86.12 \pm 15.76 \\
2.23 \pm 0.52 \\
1.82 \pm 1.23 \\
76.25 \pm 7.20 \\
78.24 \pm 17.32\end{array}$ \\
\hline
\end{tabular}

percentage of the predicted level according to Baldwin's formula. From the maximal expiratory flow volume curves (MEFV) obtained, the mean values of the peak expiratory flow rate (PEFR) and the maximal expiratory flow rate at $75 \%, 50 \%$, and $25 \%$ of the average vital capacity $\left(\dot{\mathrm{V}}_{75}, \dot{\mathrm{V}}_{50}, \dot{\mathrm{V}}_{25}\right.$, respectively), were determined. These values were standardised for height $(\mathrm{m})$.

\section{Results}

The data obtained for the four groups are summarised in tables 1 and 2 and the results of significance testing shown in table 3.

To show the impairment patterns of lung function we used the percentage of the predicted VC and $\mathrm{FEV}_{1} / \mathrm{FVC} \%$ as indices. When the percentage of the predicted VC was lower than $80 \%$ we considered it to be a restrictive defect; when the $\mathrm{FEV}_{1} / \mathrm{FVC} \%$ was lower than $70 \%$ we considered it as an obstructive defect. The results are shown in table 4. The major impairments in CWP were obstructive and mixed.

\section{Comment}

There have been several studies of lung function in coalworkers' pneumoconiosis, ${ }^{1-3}$ but the real effects of coal dust on lung function are still the subject of debate. According to the data presented here, the mean values of VC, FVC, $\mathrm{FEF}_{25-75 \%}, \mathrm{PEFR} / \mathrm{H}$, $\dot{\mathrm{V}}_{50} / \mathrm{H}, \mathrm{FEV}_{1} / \mathrm{FVC} \%$, and the percentage of pre- 
Table 2 Results of MEFV measurement (mean $\pm S D$ )

\begin{tabular}{|c|c|c|c|c|}
\hline Parameter & $\begin{array}{l}\text { (A) } \\
\text { Controls }(n=30)\end{array}$ & $\begin{array}{l}\text { (B) } \\
\text { Miners exposed to } \\
\text { dust }(n=30)\end{array}$ & $\begin{array}{l}\text { (C) } \\
\text { Patients with simple } \\
C W P(C)(n=56)\end{array}$ & $\begin{array}{l}(D) \\
\text { Patients with } \\
\text { complicated } C W P \\
(n=36)\end{array}$ \\
\hline $\begin{array}{l}\text { PEFR/H(L/S/M) } \\
\dot{V}_{75} / \mathbf{H}(\mathrm{L} / \mathrm{S} / \mathrm{M}) \\
\dot{\mathrm{V}}_{50} / \mathbf{H}(\mathrm{L} / \mathrm{S} / \mathrm{M}) \\
\dot{\mathbf{V}}_{25} / \mathbf{H}(\mathrm{L} / \mathrm{S} / \mathrm{M}) \\
\mathbf{V}_{50} / \mathbf{V}_{25}(\%)\end{array}$ & $\begin{array}{l}4.08 \pm 1.23 \\
3.58 \pm 0.68 \\
2.32 \pm 0.58 \\
0.88 \pm 0.32 \\
2.56 \pm 0.62\end{array}$ & $\begin{array}{l}3.90 \pm 1.03 \\
3.34 \pm 0.79 \\
2.29 \pm 0.66 \\
0.86 \pm 0.34 \\
2.48 \pm 0.53\end{array}$ & $\begin{array}{l}3.71 \pm 1.22 \\
2.77 \pm 1.13 \\
1.46 \pm 0.82 \\
0.66 \pm 0.63 \\
2.43 \pm 0.67\end{array}$ & $\begin{array}{l}3.12 \pm 1.24 \\
2.47 \pm 0.78 \\
1.26 \pm 0.56 \\
0.51 \pm 0.37 \\
2.54 \pm 0.79\end{array}$ \\
\hline
\end{tabular}

Table 3 Statistical significance of differences among groups ( $p$ value)

\begin{tabular}{|c|c|c|c|c|c|c|}
\hline & $A v B$ & $A v C$ & $A \cup D$ & $B v C$ & $B \cup D$ & $C v D$ \\
\hline $\begin{array}{l}\text { VC } \\
\text { VC }(\% \text { of pred) } \\
\text { FVC } \\
\text { FVC }(\% \text { of pred) } \\
\text { FEV }_{1} \\
\text { FEF }_{25}-75 \% \\
\text { FEV }_{1} / \text { FVC } \\
\text { FEV }_{1} / \text { VCPR } \\
\text { PEFR/H } \\
\dot{V}_{75} / \mathbf{H} \\
\dot{V}_{50} / \mathbf{H} \\
\dot{V}_{25} / \mathbf{H} \\
\dot{V}_{50} / \dot{V}_{25}\end{array}$ & $\begin{array}{l}\text { NS } \\
\text { NS } \\
\text { NS } \\
\text { NS } \\
\text { NS } \\
\text { NS } \\
\text { NS } \\
\text { NS } \\
\text { NS } \\
\text { NS } \\
\text { NS } \\
\text { NS } \\
\text { NS }\end{array}$ & $\begin{array}{l}<0.05 \\
<0.05 \\
\text { NS } \\
\text { NS } \\
<0.05 \\
<0.05 \\
<0.05 \\
\text { NS } \\
\text { NS } \\
\text { NS } \\
<0.01 \\
\text { NS } \\
\text { NS }\end{array}$ & $\begin{array}{l}<0.01 \\
<0.01 \\
<0.01 \\
<0.01 \\
<0.01 \\
<0.01 \\
<0.01 \\
<0.05 \\
<0.01 \\
<0.01 \\
<0.01 \\
<0.05 \\
\text { NS }\end{array}$ & $\begin{array}{l}\text { NS } \\
<0.05 \\
\text { NS } \\
\text { NS } \\
\text { NS } \\
\text { NS } \\
\text { NS } \\
\text { NS } \\
\text { NS } \\
\text { NS } \\
<0.05 \\
\text { NS } \\
\text { NS }\end{array}$ & $\begin{array}{l}<0.01 \\
<0.01 \\
<0.05 \\
<0.01 \\
<0.01 \\
<0.01 \\
<0.01 \\
<0.05 \\
<0.05 \\
<0.01 \\
<0.01 \\
<0.05 \\
\text { NS }\end{array}$ & $\begin{array}{l}\text { NS } \\
<0.01 \\
\text { NS } \\
<0.01 \\
<0.05 \\
<0.05 \\
<0.05 \\
\text { NS } \\
<0.05 \\
\text { NS } \\
\text { NS } \\
\text { NS } \\
\text { NS }\end{array}$ \\
\hline
\end{tabular}

${ }^{*} \mathrm{NS}=$ Difference between groups not significant $(\mathrm{p}>0.05$, paired $t$ test)

Table 4 Impairment patterns of lung function

\begin{tabular}{|c|c|c|c|c|c|c|c|c|}
\hline \multirow{2}{*}{$\begin{array}{l}\text { Pattern } \\
\\
\text { Obstructive } \\
\text { Restrictive } \\
\text { Mixed } \\
\text { Normal }\end{array}$} & \multicolumn{2}{|c|}{ Controls $(n=30)$} & \multicolumn{2}{|c|}{$\begin{array}{l}\text { Miners exposed to } \\
\text { dust }(n=30)\end{array}$} & \multicolumn{2}{|c|}{$\begin{array}{l}\text { Patients with simple } \\
C W P(n=65)\end{array}$} & \multicolumn{2}{|c|}{$\begin{array}{l}\text { Patients with } \\
\text { complicated CWP } \\
(n=36)\end{array}$} \\
\hline & $\begin{array}{c}N o \\
0 \\
0 \\
0 \\
30\end{array}$ & $\begin{array}{r}\% \\
0 \\
0 \\
0 \\
100\end{array}$ & $\begin{array}{c}N o \\
3 \\
0 \\
1 \\
26\end{array}$ & $\begin{array}{c}\% \\
10 \cdot 0 \\
0 \\
3 \cdot 3 \\
86.7\end{array}$ & $\begin{array}{c}N o \\
10 \\
2 \\
5 \\
48\end{array}$ & $\begin{array}{r}\% \\
15.4 \\
3.1 \\
7.7 \\
73.8\end{array}$ & $\begin{array}{r}\text { No } \\
9 \\
3 \\
6 \\
18\end{array}$ & $\begin{array}{r}\% \\
25.0 \\
8.3 \\
16.7 \\
50.0\end{array}$ \\
\hline
\end{tabular}

dicted VC and FVC in patients with complicated CWP are much lower than those in healthy controls and in miners exposed to coal dust $(p<0.01)$. These parameters in patients with simple CWP were lower than those in healthy controls $(p<0.05)$, but there were no significant differences between the patients with simple CWP and miners exposed to coal dust $(p>0.05)$. Lung function, including small airways function, in these patients with CWP was definitely impaired, but the extent of the impairment and the reduction in lung function was related to the severity of the CWP; the changes in complicated CWP were more severe than in simple CWP. The major impairments in lung function were of an obstructive and a mixed type. There were no significant differences between the patients with simple CWP and the miners exposed to coal dust, or between the miners exposed to coal dust and the healthy controls $(p>0.05)$.

It has been suggested that the disparate findings of some reports may be attributable to the various geographical locations of the studies ${ }^{24}$ and cigarette smoking must be considered as a major factor in the in the impairment of lung function in coalminers. ${ }^{2}$

In the present study all the subjects came from one region and about $38-45 \%$ of the subjects in all four groups were smokers. Cigarette smoking may have played a part in the deterioration in lung function but the impairment was also inversely related to exposure to coal dust. There may have been a synergic or additive effect between smoking and coal dust on the lung function in these subjects.

\section{References}

1 Ashford JR, Brown S, Morgan DC, Rae S. The pulmonary ventilatory function of coal miners in the United Kingdom. Am Rev Respir Dis 1968;97:810-8.

2 Morgan WKC, Handelsman L, Kibelstis J, et al. Ventilatory capacity and lung volumes of US coal miners. Arch Environ Health 1974;28:182-9.

3 Musk AW, Cotes JE, Bevan C, Campbell MJ. Relationship between type of simple coalworkers' pneumoconiosis and lung function. A nine-year follow-up study of subjects with small rounded opacities. Br J Ind Med 1981;38:313-20.

4 Cochrane AL, Higgins ITT. Pulmonary ventilatory functions of coal miners in various areas in relation to the $\mathrm{x}$-ray category of pneumoconiosis. Br J Prev Soc Med 1961;15:1-11. 